\title{
Study of Organic Substance (Myrmecodia pendans) Extraction Using Soxhletation Method as an Organic Inhibitor
}

\author{
Tubagus Noor Rohmannudin ${ }^{1, \text { a) }}$, Sulistijono ${ }^{1, \mathrm{~b})}$, Muhammad Adiyaksa ${ }^{1, \mathrm{c})}$, \\ Mochamad Alvan Mifta Chusururi ${ }^{1, \mathrm{~d})}$ \\ ${ }^{1}$ Dept. of Materials Engineering, Sepuluh Nopember Institute of Technology, Surabaya, Indonesia \\ a) Corresponding author: roma_r2001@yahoo.com \\ b)sulistijono@mat-eng.its.ic.id \\ c)adimyaksa@gmail.com \\ d)mchusururi@gmail.com
}

\begin{abstract}
Extract of natural substance is currently being developed as an organic inhibitor. Organic inhibitor can be used to inhibit corrosion rate of metallic material especially steel. The purpose of this study is to analyze the effectiveness of soxhletation extraction methods and the quality of inhibitor of Sarang Semut (Myrmecodia pendans) extract. The variations implemented in this research were the composition of the solvent-material and the content comparison of flavonoid compounds. The results of Sarang Semut (Myrmecodia pendans) extract inhibitor using soxhletation extraction method was observed qualitatively and quantitatively This research used soxhletation extraction method, simplicia Sarang Semut (Myrmecodia pendans) powder as the organic substance, and a mixture of acetone and distilled water as the solvent. Ratio variation of the solvent-substance composition used are 1:10, 1:15, and 1:20. Tests used in this study were Extract Parameters, FTIR, TLC and UV-Vis Spectrophotometry and weight loss. The highest yield was shown when using 1:10 ratio which was $13.943 \%$, the total ash content and the lowest extracted water content shown at a ratio of 1:10 with amount of $4.26 \%$ and $4.2483 \%$. FTIR test results indicated functional groups of flavonoids compounds and TLC test showed positive results of Flavonoid compounds which were characterized by blackish discoloration. The highest percentage of flavonoid compounds of $0.22025 \%$ found at the $1: 10$ ratio. The highest efficiency inhibition happened when weight loss testing showed 500ppm with the result of $84.3 \%$.
\end{abstract}

\section{INTRODUCTION}

Corrosion is a major problem in the industry, especially the oil and gas industry which mostly use carbon steel material as the equipment or the components. Corrosion is degradation of a material as the result of reaction with environment (Fontana, 1987). Corrosion results to the very large loss on an oil and gas industry plant if the control of corrosion is not carried out. Losses include cessation of production processes and safety of workers (Wahyuningsih, Sunarya, \& Aisyah, 2010).

One method of corrosion control can be done using inhibitor as a substance to inhibit corrosion rate in the industrial piping system. The use of these corrosion inhibitors is highly potential to handle the corrosion problems that occur in the inner layer of a carbon steel (Priatna, 2015). One of the organic inhibitor that can reduce the corrosion rate coming from plants are Myrmecodia pendans species. Results of ant plant extract have been analyzed before and those plants are proven to contain flavonoids. Flavonoids serves as a useful antioxidant compound in the manufacture of green inhibitors. Soxhletation extraction method is a method used to produce organic inhibitors from natural substance. 
Extraction using soxhletation provides useful benefits compared to other processes, i.e. a faster extraction process, continuous process, and quality improvement of the extract generated.

This research will investigate the process of soxhletation and its correlation to the quality of the organic inhibitor of Sarang Semut (Myrmecodia pendans). Then, the researcher will compare qualitatively and quantitatively the flavonoid compounds contained in Sarang Semut (Myrmecodia pendans) extract.

\section{MATERIALS AND METHODS}

\section{Materials}

The material used in this study was ant's nest tuber from Wamena, Papua and a mixture of acetone and distilled water as the solvent. Other material included were $2 \% \mathrm{FeCl}_{3}, 96 \%$ ethanol, filter paper, chloroform-methanol (9:1), and KLT Kiesel Gel GF254 plate.

\section{Specimen Preparation}

Specimen used was API 5L grade B in the weight loss testing. Dimension for specimen was 20x20x3 mm before immersion in the electrolyte, specimen must be smoothed by using the rubbing paper in the surface.

\section{Extraction Process}

The extraction process began with the drying process and refinement of Sarang Semut (Myrmecodia pendans) to produce simplicia powder. Simplicia of ant nest tuber Sarang Semut (Myrmecodia pendans) powder used in the extract process was 100 grams for each variation of solvent-material ratio. A mixture of acetone-distilled water with a ratio of 7:3 was used as the solvent. Volume of the acetone-distilled water mixtures used were i.e. $1000 \mathrm{~mL}, 1500 \mathrm{~mL}$, and $2000 \mathrm{~mL}$, then the comparison of solvent-material were of 1:10, 1:15, and 1:20 could be obtain. Furthermore, soxhletation extraction process was done to each of the solvent ratio at $50^{\circ} \mathrm{C}$. Extract resulting from the soxhletation process were concentrated using rotary evaporator at a temperature of $60^{\circ} \mathrm{C}$. After the concentrating the extract, all three extract samples were dried and weighed to count the yield value.

\section{Extraction Parameters}

The extract parameters are divided into two parameters, i.e. determination of total ash content and water content of the extract. For determination of total ash content, the sample extract is wieghed as much as \pm 1 gram and heated it at a temperature $625^{\circ} \mathrm{C}$ for 5 hours. Determination of water content of the extract was carried out using weighing as much as \pm 1 gram and heating on temperature of $105^{\circ} \mathrm{C}$ for 5 hours.

\section{Characterizations}

Fourier Transform Infra Red Spectroscopy (FTIR)

FTIR (Fourier Transform Infrared) testing was used to identify the chemical functional groups of the three extract samples of Sarang Semut (Myrmecodia pendans). Chemical functional group extract provided a qualitative analysis and indicated the existence the compounds. Sample of ant's nest tuber extract with the solvent ratio of 1:10, 1:15, and 1:20 resulting from soxhletation extraction process were analyzed for the functional groups of the flavonoid compounds groups.

\section{Thin Layer Chromatography (TLC)}

Testing of thin layer chromatography for phytochemical screening was used for the three extract samples. This test was qualitative. The stationary phase used was the Kiesel Gel GF 254 thin plate. The mobile phase used was a chloroform-methanol solution with 9:1 ratio and $2 \% \mathrm{FeCl}_{3}$ smear. Positive indication flavonoid group compounds were identified from brownish to blackish discoloration with bottling of $2 \% \mathrm{FeCl}_{3}$ smear appearance. 


\section{UV-Vis Spectrophotometry}

UV-Vis spectrophotometric testing was used to analyze total aggregation of the flavonoid compound class on Sarang Semut (Myrmecodia pendans) extract. The testing process included sample preparation, assaying, making blank solution, and measurements. Samples were measured on a spectrophotometric device UV-Vis with wavelength range 300 - $500 \mathrm{~nm}$ in order to obtain maximum absorbance on each extract.

\section{Weight Loss Testing}

First, specimens were weighed to get the initial weight after immersion in $1000 \mathrm{ml}$ a solution of $1 \mathrm{M} \mathrm{HCl}$. Second, the various concentration of 100, 200, 300, 400, $500 \mathrm{mg} / \mathrm{l}$ were applied in immersion time as long as 2 hours in the room temperature. Following equation was used to calculate the inhibition efficiency:

$$
\begin{aligned}
& C R=\frac{k \cdot w}{D \cdot A \cdot T} \\
& \% E I=\frac{C R 0-C R 1}{C R 0} \times 100 \%
\end{aligned}
$$

Where $\mathrm{K}$ is a constant corrosion rate, $\mathrm{D}$ is density, $\mathrm{W}$ is the weight of the specimen, and $\mathrm{A}$ is the surface area of specimen, CR0 is the efficiency absence of inhibitors, and CR1 is the efficiency presence of inhibitors.

\section{RESULTS AND DISCUSSION}

\section{Extraction Process Result}

The extraction process began with the drying process and refinement of Sarang Semut (Myrmecodia pendans) to produce simplicia powder. Simplicia of ant nest tuber Sarang Semut (Myrmecodia pendans) powder used in the extract process was 100 grams for each variation of solvent-material ratio.

Table 1. shows the results of soxhletation extraction for all three sample with solvent-material variation. The table includes the volume of liquid extract, extraction time, and yield value.

TABLE 1. Results of Soxhletation Extraction Process

\begin{tabular}{cccc}
\hline No. & $\begin{array}{c}\text { Solvent-Material } \\
\text { Ratio }\end{array}$ & $\begin{array}{c}\text { Extract Volume } \\
(\mathbf{m L})\end{array}$ & Extraction Time \\
\hline 1 & $1: 10$ & 300 & 2 hours 7 minutes \\
2 & $1: 15$ & 770 & 2 hours 12 minutes \\
3 & $1: 20$ & 990 & 2 hours 9 minutes \\
\cline { 1 - 2 } Average & & 2 hours 9.3 minutes \\
\hline
\end{tabular}

Based on the table above, on the 1:10 solvent-material ratio, volume of liquid Sarang Semut (Myrmecodia pendans) extract which was extracted using soxhletation was $300 \mathrm{~mL}$ and the extraction time for 2 hours 7 minutes were obtained. For the 1:15 solvent-material ratio, volume of liquid nest tuber extract, extracted using soxhletation was 770 $\mathrm{mL}$ and extraction time for 2 hours 12 minutes were obtained. And for 1:20 solvent-material ratio, the liquid volume of extract was $990 \mathrm{~mL}$ and extraction time for 2 hours 9 minute were obtained. Longest time of extraction between those three were at a ratio of 1:10, but the length of extraction processing time on each composition ratio did not show any significant differences. The average time of extraction process of Sarang Semut (Myrmecodia pendans) using soxhletation was 2 hours 9.3 minutes. Usage of soxhletation extraction methods requires less time and more capacity between the material and the solvent compared to the process of maceration extraction. The process of organic substance extraction in the term of heat were more effective, as well as the time efficiency, but the process requires a volatile solvent or low boiling point temperatures. Extraction with soxhlet gave higher extract results because in this way the heating was used to improve solubility of the extract (Pambayun, Gardjito, Sudarmadji, \& Kuswanto, 2007). 


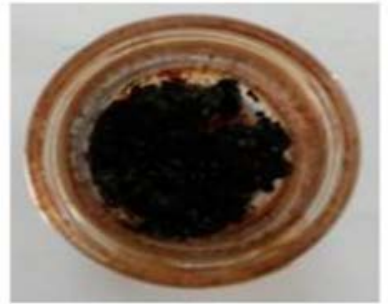

(a)

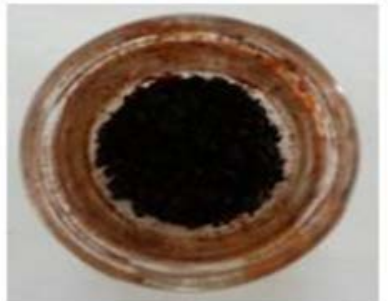

(b)

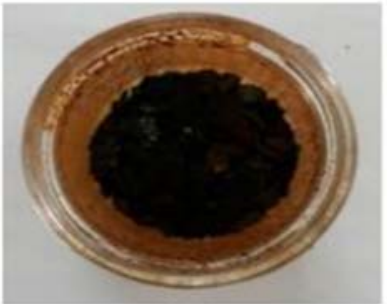

(c)

FIGURE 1. Dried extract of Sarang Semut (Myrmecodia pendans) from soxhletation extraction. (a) 1:10 solvent-material ratio, (b) 1:15 solvent-material ratio, and (c) 1:20 solvent-material ratio

Figure 1. (a) shows the dry extract results of Sarang Semut (Myrmecodia pendans) from soxhletation extraction process on 1:10 solvent-material ratio, (b) 1:10 solvent-material ratio, and (c) 1:20 solvent-material ratio. The three extracts show the same organoleptic, which is dry and solid, blackish brown, and with distinctive smell.

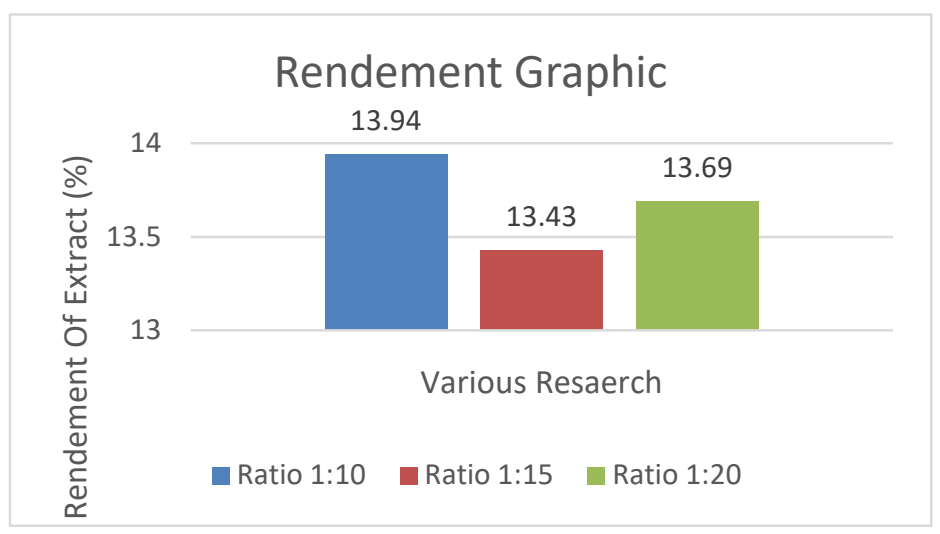

FIGURE 2. Yield Results from Extraction Process

The fluctuating value of the rendement is shown in all three range of solvent-material ratio in the figure 2, the decrease of rendement value of the extract occurred at ratio of 1:15 and then improved on 1:20 ratio which is not too significant. The value of the extract rendement shows the ability of the solvent to dissolve the compounds contained in powder simplicia. In this study, the value the yield of Sarang Semut (Myrmecodia pendans) extract is affected by volume of solvent and does not depend on the amount of simplicia which is used for extract Sarang Semut (Myrmecodia pendans) powder.

The optimum point is reached in the solvent-material ratio of 1:10 or $1000 \mathrm{~mL}$ solvent volume, so the addition of solvent more than $1000 \mathrm{~mL}$ is no longer effective to increase the weight of extract of Sarang Semut (Myrmecodia pendans) from the extraction process. The components contained in the material are limited and the solvents which is used has a limited capability to dissolve the existing materials. In the other words, it is the optimal solubility limit of acetone-distilled water solvent.

\section{Results of Extraction Parameters}

The extract parameters are divided into two parameters. determination of total ash content and water content of extract. The total ash content percentage value of ant's nest simplicia powder and the three extracts samples of acetonedistilled water Sarang Semut (Myrmecodia pendans) generated from soxhletation extraction process are shown in table 2. 
TABLE 2. Total ash content and water content of extract

\begin{tabular}{cccc}
\hline No. & Sample Name & $\begin{array}{c}\text { Total Ash Content } \\
\mathbf{( \% )}\end{array}$ & $\begin{array}{c}\text { Water Content of } \\
\text { Extract (\%) }\end{array}$ \\
\hline 1 & Ant's Nest Simplicia & 3,92 & 1,55 \\
2 & 1:10 Ratio & 4,26 & 4,25 \\
3 & 1:15 Ratio & 7,78 & 4,53 \\
4 & 1:20 Ratio & 7,61 & 4,36 \\
\hline
\end{tabular}

On ant nest simplicia powder, we obtained the value of total ash content as much as 3.92\%, 4.26\% at 1:10 solventmaterial ratio, then rose to $7.78 \%$ at $1: 15$ ratio and decreased to $7.61 \%$ at $1: 20$ ratio. The standard total ash content of the Sarang Semut (Myrmecodia pendans) extract is no more than $11.13 \mathrm{~g} / 100 \mathrm{~g}$ or $11.13 \%$ (Subroto \& Saputro, 2006). All three sample on this study has met the total ash content standards, i.e. less than $11.13 \%$. Based on the determination of total ash content of the three samples of the extract, the simplicia powder has percentage of total ash content of $3.92 \%$. Whereas, on sample extract with a 1:10 solvent-material ratio shows the smallest percentage of total ash content, i.e. amounting to $4.26 \%$. At 1:15 solvent-material ratio shows the highest percentage of total ash content, that is equal to $7.78 \%$. The total ash content indicates the presence of mineral contaminant's and metal oxide in the extract. The higher the ash content total, the higher the contaminant is contained in in the extract.

In Sarang Semut (Myrmecodia pendans) simplicia have percentage water content of 1.55\%, 1:10 ratio has percentage of water content of extract equal to $4,25 \%$, ratio $1: 15$ has a water content percentage of extracts amounting to $4.53 \%$, and $1: 20$ ratio has a percentage of water content of the extract amounting to $4.36 \%$. Of the three samples extract shown there is a fluctuation tendency to the water content percentage. The increase of percentage shown in the extract with a 1:15 solvent-material ratio and the decrease happens in the 1:20 ratio.

Simplisia of Sarang Semut (Myrmecodia pendans) powder used in the extraction process has a percentage of water content that is very low, i.e. at $1.55 \%$. It makes simplicia powder from Sarang Semut (Myrmecodia pendans) is feasible to do extraction process and has been in accordance with the water content standards for simplicia described according to (Departemen Kesehatan RI, 1980), that the simplicia is assessed to be safe to have a water content of less than $10 \%$. The standard for the moisture content of the ant nest tuber extract is not exceeding $4.54 \mathrm{~g} / 100 \mathrm{~g}$ or $4.54 \%$. Third sample extract with a ratio of 1:10, 1:15, and 1:20 have water content less than 4.54\% (Departemen Kesehatan RI, 1980). It shows that Sarang Semut (Myrmecodia pendans) acetone-distilled water extracts from the soxhletation extraction met the standards for water content.

The lowest value of the extracted water content is shown on 1:10 solvent-material ratio, which is $4.25 \%$. The highest water content value is in the ratio of $1: 15$, that is equal to $4.53 \%$. Water content is an important factor in determination of the quality of an extracted organic substance. Water content also determines the durability of the extract during the process storage. Products that contained higher water content are easier to damaged because the product can become a medium conducive to the growth of microorganisms (Pardede, Ratnawati, \& Putranto, 2013).

\section{Fourier Transform Infrared Spectroscophy (FTIR)}

FTIR testing is performed to identify the presence functional group of flavonoid group compounds. The following are graphs and tables of FTIR results of Sarang Semut (Myrmecodia pendans) extract.

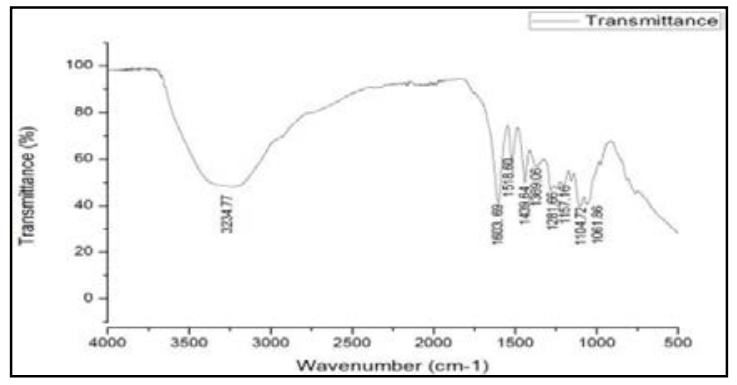

FIGURE 3. FTIR graph of Sarang Semut (Myrmecodia pendans) extract 
TABLE 3. FTIR graph of Sarang Semut (Myrmecodia pendans) extract

\begin{tabular}{|c|c|c|c|c|}
\hline No & $\begin{array}{c}\text { Wavenumber } \\
(\mathrm{cm}-1)\end{array}$ & Chain & Type Compound & Intensity \\
\hline 1 & 3227.55 & $\mathrm{O}-\mathrm{H}$ & $\begin{array}{l}\text { Phenol, alcohol } \\
\text { hydrogen bond, } \\
\text { alcohol monomers }\end{array}$ & $\begin{array}{c}\text { Changing, } \\
\text { sometimes } \\
\text { widened }\end{array}$ \\
\hline 2 & 1604.14 & $\mathrm{C}=\mathrm{C}$ and $\mathrm{CO}$ & Alkene & Changing \\
\hline 3 & 1518.65 & $C=C$ & $\beta$-diketon & Changing \\
\hline 4 & 1440.67 & $\mathrm{C}-\mathrm{H}$ & Aromatic Ring & \\
\hline 5 & 1370.66 & -C-NO2 & Alkana & Strong \\
\hline 6 & 1282.01 & $\mathrm{C}-\mathrm{N}$ & Nitro Aromatic & \\
\hline 7 & 1104.79 & $\mathrm{C}-\mathrm{O}$ & Amida, Amina & Strong \\
\hline 8 & 1062.57 & $\mathrm{C}-\mathrm{O}$ & $\begin{array}{c}\text { Alcohol, Ether, } \\
\text { Acid } \\
\text { Carboxylate, } \\
\text { Esther }\end{array}$ & Strong \\
\hline
\end{tabular}

Based on the table 3 graph data above, the FTIR test results shows that Sarang Semut (Myrmecodia pendans) extract has various chemical functional groups. There are nine functional groups chemistry on the composition ratio of 1:10 and 1:20, among them the functional group $\mathrm{O}-\mathrm{H}$ (Phenol, hydrogen bonding alcohol, monomer alcohol) with changing intensity and sometimes widened intensity, $\mathrm{C}=\mathrm{C}$ (Alkene) with changing intensity, $\mathrm{CO}$ ( $\beta$-diketone), $\mathrm{C}=$ $\mathrm{C}$ (Aromatic Ring) with changing intensity, $\mathrm{C}-\mathrm{H}$ (Alkane) with strong intensity, $-\mathrm{C}-\mathrm{NO}_{2}$ (Nitro Aromatic), $\mathrm{NO}_{2}$ with strong intensity, $\mathrm{C}-\mathrm{N}$ (Amide, Amine) with strong intensity, and $\mathrm{C}-\mathrm{O}$ (Alcohol, Ether, Carboxylic Acid, Esther). The chemical functional groups $\mathrm{O}-\mathrm{H}, \mathrm{C}=\mathrm{C}$ (Alkene), $\mathrm{C}=\mathrm{C}$ (Aromatic Ring), $\mathrm{C}-\mathrm{H}, \mathrm{NO}_{2}, \mathrm{C}-\mathrm{O}$, and $\mathrm{N}-$ $\mathrm{H}$ are the groups function of a flavonoid compounds contained in acetone-distilled water ants' nest tuber extracts. These results supported by the study (Yuslinur, 2014) that ant's nest extract has functional groups of $\mathrm{C}-\mathrm{H}, \mathrm{C}-\mathrm{O}, \mathrm{C}$ $=\mathrm{C}, \mathrm{N}-\mathrm{H}, \mathrm{NO}_{2}$ and $\mathrm{O}-\mathrm{H}$ which is a type of flavonoid compounds. Organic compounds that can act as inhibitors should be hydrophobic and at one end of the hydrocarbon groups chain must be hydrophilic such as $\mathrm{N}, \mathrm{O}, \mathrm{OH}, \mathrm{S}$ and $\mathrm{NH}_{2}$. So, this chain of bonds is what would be a deterrent to the corrosive environment for direct contact with metal (Siagian, Sulistijono, \& Susanti, 2010). The functional groups of Alkanes C - C and C = C Alkene have hydrophobic properties so that it can be a barrier to the reaction between metal and electrolyte solution. In addition, the functional group Amines and Amides $(\mathrm{N}-\mathrm{H})$; Phenol and Alcohol hydrogen bonds $(\mathrm{O}-\mathrm{H})$ is a hydrophilic functional group. Meanwhile, the functional group $\mathrm{C}-\mathrm{O}$ for Alcohol, Ether, Acid Carboxylates, and Esters have adsorption properties. Functional groups of the compound is expected to undergo the adsorption process into the metal surface so that the metal is protected from corrosion attack coming from the environment. The three properties of the functional groups revealed that acetone-distilled water Sarang Semut (Myrmecodia pendans) extract may act as corrosion inhibitors.

\section{Thin Layer Chromatography (TLC)}

The stationary phase used is the Kiesel Gel GF thin plate 254. The dynamic phase used is chloroform-methanol solution with a ratio of 9:1 and $2 \% \mathrm{FeCl}_{3}$ smear. Results testing of phytochemical screening of flavonoid compounds using a thin layer chromatography method can be seen in Figure 4.

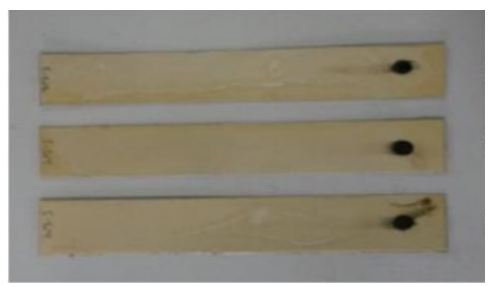

FIGURE 4. Phytochemical screening of Sarang Semut (Myrmecodia pendans) extract results from soxhletation extraction process from above to bottom are 1:10 solvent-material ratio, 1:15 solvent-material ratio, 1:20 solvent-material ratio. 
Based on Figure 4, the three sample extracts ratio of acetone-distilled water Sarang Semut (Myrmecodia pendans) extract results from soxhletation extraction process show positive results of the presence of flavonoid compounds. Once given the smearing $\mathrm{FeCl}_{3}$, the three extract samples revealed blackish color. Black color change as formation of complex compounds formed from the reaction between flavonoids and $\mathrm{FeCl}_{3}$. Indication of discoloration to black after flavonoid compound were given $\mathrm{FeCl}_{3}$ smear reported (Sunaringtyas, 2014), revealed that the color reaction test with $\mathrm{FeCl}_{3}$ is black. The extraction results that were reacted with $\mathrm{FeCl}_{3}$ produces a blackish color and indicates the presence of flavonoid compounds, namely flavonol (Dwi Rusita \& Suhartono, 2016).

\section{UV-Vis Spectrophotometry}

UV-Vis spectrophotometric testing was used to analyze the total aggregation of the flavonoid compound class on Sarang Semut (Myrmecodia pendans) extract .

Figure 5. shows the results of UV-Vis spectrophotometric testing for the three samples of Sarang Semut (Myrmecodia pendans) extract.

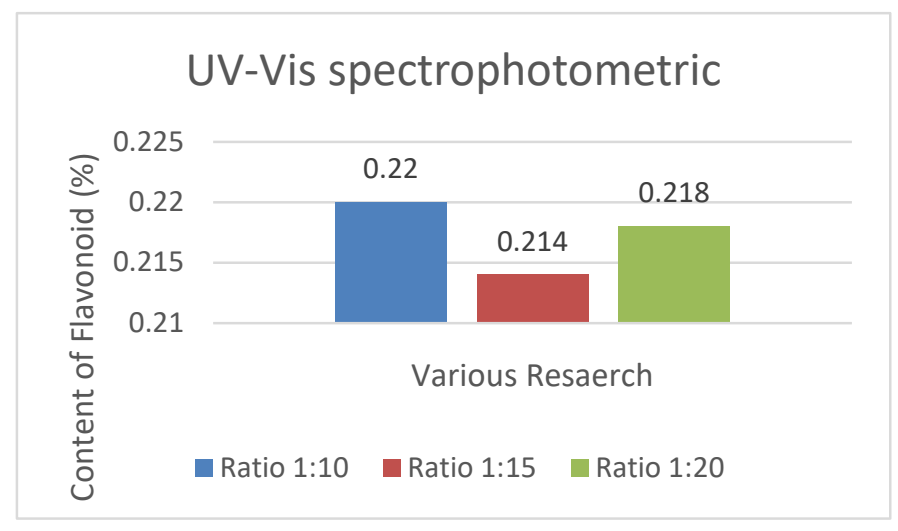

FIGURE 5. Flavonoid compound percentage graph of Sarang Semut (Myrmecodia pendans) extract.

The percentage of flavonoids from the three extract samples with the highest percentage is shown in the ratio of $1: 10$ solvent, the second highest is at $1: 20$, and the lowest is at $1: 15$. There is a decrease in the percentage of flavonoids in the 1:15 ratio and then the percentage goes back on 1:20 ratio. The graph shows a fluctuative trend from the three extract samples. The most optimal flavonoids extracted in this study was obtained on 1:10 solvent-material ratio or with a solvent of $1000 \mathrm{~mL}$. The optimum point is reached on the solvent volume of $1000 \mathrm{~mL}$, so the addition of solvent more than $1000 \mathrm{~mL}$ is no longer effective to increase the percentage of extracted flavonoids. This is due to too large a volumes lead to less turbulence which and decreases the number of flavonoids extracted (Yulianingtyas \& Kusmartono, 2016).

\section{Weight Loss Testing}

Weightloss testing method used various concentration of 100ppm, 200ppm, 300ppm, 400ppm, 500ppm in the room temperature. The result showed that concentration 500ppm have highest efficiency as much as $84,3 \%$ in the $\mathrm{HCl}$ $1 \mathrm{M}$.

The result of this data indicated that 500ppm have the highest efficiency than the others. There was a barrier on the metal surface and also the acid environment which were able to make the cause the passivation film became thicker and more stable (Pradityana, Sulistijono, \& Shahab, 2015). which will protect the metal surface direct contact with the electrolyte. but corrosion reactions still occur with the precipitation of a small element that can penetrate the barrier. but this corrosion reaction is very slow. the addition of inhibitor concentration in the indication can increase efficiency due to the formation of an increasingly compact barrier. this can be seen in table 4, can be seen the higher the concentration value is directly proportional to the value of inhibition efficiency. 
TABLE 4. Various concentrations and the efficiency of inhibitor

\begin{tabular}{cc}
\hline Concentration (ppm) & Efficiency of Inhibitor (\%) \\
\hline 0 & - \\
100 & 51.4 \\
200 & 65.5 \\
300 & 69.3 \\
400 & 76.5 \\
500 & 84.3 \\
\hline
\end{tabular}

\section{CONCLUSION}

The solvent-material compositions ratio with the best and optimal characteristic is in the composition ratio of 1:10. It is shown from the value of rendement, total ash content, and water content of each extract, that are $13.94 \%, 4.26 \%$, and 4.25\%. Qualitative testing FTIR and TLC show positive results of the flavonoid compounds content in the extract. Quantitative testing UV-Vis spectrophotometry shows the ratio of percentage values of flavonoid compound with the highest content is shown at a 1:10 ratio of $0.22 \%$. weight loss testing have highest efficiency inhibition in 500ppm.

\section{ACKNOWLEDGMENTS}

LPPM ITS Surabaya, Indonesia has provided excellent research funding for this project

\section{REFERENCES}

Departemen Kesehatan RI. (1980). Materia Medika Indonesia. Jilid IV. Jakarta: Departemen Kesehatan RI. Retrieved from http://perpustakaan.litbang.depkes.go.id/otomasi/index.php?p=show_detail\&id=8396

Dwi Rusita, Y., \& Suhartono. (2016). Flavonoids content in extracts secang (Caesalpinia Sappan L.) maceration method infundation analysis and visible ultraviolet spectrophotometer. International Journal of Medical Research \& Health Sciences, 5(4), 176-181.

Fontana, M. (1987). Corrosion Engineering. . Singapore: McGraw-Hill.

Pambayun, R., Gardjito, M., Sudarmadji, S., \& Kuswanto, K. R. (2007). Kandungan fenol dan sifat antibakteri dari berbagai jenis ekstrak produk gambir (Uncaria gambir Roxb) Phenolic content and antibacterial properties of various extracts of gambir (Uncaria gambir Roxb). Majalah Farmasi Indonesia, 18(3), 141-146.

Pardede, A., Ratnawati, D., \& Putranto, A. M. H. (2013). Ekstraksi dan karakterisasi pektin dari kulit kemiri (Alleurites Mollucana Willd). Media Sains, 5(1), 1-6.

Pradityana, A., Sulistijono, \& Shahab, A. (2015). The Influence of Adding Bio Inhibitor Sarang Semut (Myrmecodia pendans) to Carbon Steel API 5L Grade B in Solution of HCl 1 M. Advanced Materials Research, 1123, 187191. https://doi.org/10.4028/www.scientific.net/AMR.1123.187

Priatna, E. (2015). Potensi Protoporfirin dari Limbah Darah Hasil Pemotongan Sapi sebagai Inhibitor Korosi Baja Karbon dalam Larutan H2SO4 0,5 M. Universitas Pendidikan Indonesia.

Siagian, F. R., Sulistijono, \& Susanti, D. (2010). Pengaruh Variasi Konsentrasi Inhibitor Tapioka terhadap Laju Korosi dan Perilaku Aktif Pasif Stainless Steel AISI 304 dalam Media Air Laut Buatan. Institut Teknologi Sepuluh Nopember.

Subroto, A., \& Saputro, H. (2006). Gempur penyakit degan sarang semut. Tangerang: Penebar Swadaya.

Sunaringtyas, J. (2014). Efek Pemberian Ekstrak daun Ciremai (Phyllanthus acidus (L.) Skeels.) terhadap Titer Widal O dan Suhu Tubuh Mencit Balb/C yang Diinfeksi Salmonella typhi. STIKES Ngudi Waluyo.

Wahyuningsih, A., Sunarya, Y., \& Aisyah, S. (2010). Metanamina sebagai Inhibitor Korosi Baja Karbon dalam Lingkungan Sesuai Kondisi Pertambangan Minyak Bumi. Jurnal Sains Dan Teknologi Kimia, 1(1), 17-29.

Yulianingtyas, A., \& Kusmartono, B. (2016). Optimasi Volume Pelarut dan Waktu Maserasi Pengambilan Flavonoid Daun Belimbing Wuluh (Averrhoa bilimbi L.). Jurnal Teknik Kimia, 10(2), 58-64.

Yuslinur. (2014). Studi Analisis Campuran Eco-Friendly Inhibitor Ekstrak Sarang Semut (Myrmecodia pendans) dan Daun Sirih Merah (Piper crocatum) terhadap Laju Korosi Baja API 5L Grade B di Lingkungan NaCl 3,5\%. Institut Teknologi Sepuluh Nopember. 